\title{
Sulfenate Esters of Simple Phenols Exhibit Enhanced Activity against Biofilms
}

Danica J. Walsh*1,2, Tom Livinghouse ${ }^{* 1}$, Greg M. Durling ${ }^{1}$, Yenny Chase-Bayless ${ }^{4}$, Adrienne D. Arnold $^{3,2}$, Philip S. Stewart ${ }^{2}$

${ }^{1}$ Chemistry and Biochemistry, Montana State University, Bozeman, MT, 59717, USA

${ }^{2}$ Center for Biofilm Engineering, Montana State University, Bozeman, MT, 59717, USA

${ }^{3}$ Microbiology and Immunology, Montana State University, Bozeman, MT, 59717, USA

${ }^{4}$ Fish and wildlife, Montana State University, Bozeman, MT, 59717, USA

*Correspondence should be addressed to Tom Livinghouse; thomas.livinghouse@ montana.edu or Danica Walsh; danica.walsh@montana.edu

Keywords: Biofilms; Anti-biofilm; Antimicrobial; Sufenate esters

\begin{abstract}
The recalcitrance exhibited by microbial biofilms to conventional disinfectants has motivated the development of new chemical strategies to control and eradicate biofilms. The activity of several small phenolic compounds and their trichloromethylsulfenyl ester derivatives were evaluated against planktonic cells and mature biofilms of Staphylococcus epidermidis and Pseudomonas aeruginosa. Some of the phenolic parent compounds are well-studied constituents of plant essential oils, for example, eugenol, menthol, carvacrol and thymol. The potency of sulfenate ester derivatives was markedly and consistently increased both towards planktonic cells as well as biofilms. The mean fold difference between parent and derivative minimum inhibitory concentration against planktonic cells was 44 for $S$. epidermidis and 16 for $P$. aeruginosa. The mean fold difference between parent and derivative biofilm eradication concentration for twentytwo tested compounds against both $S$. epidermidis and $P$. aeruginosa was 3 . This work demonstrates the possibilities of a new class of biofilm-targeting disinfectants deploying a sulfenate ester functional group to increase antimicrobial potency towards microorganisms in biofilms.
\end{abstract}

\section{Introduction}

Biofilms are multicellular communities that form when planktonic cells adhere to a surface via cell adhesions structures such as pili or flagella ${ }^{1-2}$. Attached cells begin to secrete extracellular DNA, proteins and polysaccharides to form an extracellular polymeric substance (EPS), which traps nutrients while providing protection from antimicrobials, disinfectants and host immune defences $^{3-7}$. In the biofilm interior, cells experience slow growth rates or become dormant and are able to persist when other cells in the biofilm are killed. These persistent cells are able to regenerate the biofilm, resulting in chronic infection and contribute greatly to the refractory characteristics of biofilms ${ }^{8-12}$. Reactive antimicrobial agents may be retarded in their penetration if they are neutralized as they diffuse into the biofilm ${ }^{13-17}$. These factors all contribute to increased tolerance towards antibacterial agents and disinfectants ${ }^{11,18-23}$. It is due to traits such as these and biofilms prominence in hospitals that lead to elevated efforts to control biofilms with small molecules ${ }^{24}$. 
Over the last two decades the number of hospital-acquired infections has increased by $36 \%$ in the US, further stressing the need for novel disinfectants ${ }^{25}$. Routine disinfectants that are currently used in hospitals include hydrogen peroxide, sodium hypochlorite, chlorine and quaternary ammonium salts; although many of these have serious shortcomings when treating biofilms. For example, several studies have shown that $P$. aeruginosa and $E$. coli biofilms exhibit resistance toward hydrogen peroxide ${ }^{26-28}$. Bacterial strains prevalent in hospitals such as $S$. aureus and $P$. aeruginosa have also been shown to exhibit tolerance toward many quaternary ammonium salts such as benzalkonium chloride, benzyldimethyltetradecylammonium chloride, didecyldimethylammonium bromide ${ }^{29-31}$. Chlorine and chlorine dioxide have been shown to have limited potency toward biofilms due to its inability to fully penetrate through the robust EPS, thus being unable to reach the inner layers of the biofilm ${ }^{32-33}$. Essential oils such as thymnol and eugenol are use as environmentally friendly disinfectants to control $S$. aureus biofilms, although are used at high concentrations in order to be effective ${ }^{34}$.

Phenols are a well-studied class of organic compounds which have been shown to demonstrate varying degrees of antimicrobial activity ${ }^{35-37}$ and were chosen here due to a wide variety of structurally diverse phenols being previously evaluated for biological activity ${ }^{38-46}$. Among these activities, phenols have been shown to disrupt the cell membrane causing cell lysis, resulting in cell death ${ }^{41,45,47-48}$. Phenols have also been shown to attack cytoplasmic targets by denaturing proteins and deactivating enzymes, thereby binding to them to form inoperative complexes ${ }^{43,46}$. The majority of phenols selected for this study were done so for their previously known antimicrobial activity towards planktonic cells. The essential oils thymol, menthol, carvacrol and eugenol were chosen for their inhibitory and antimicrobial properties against a wide range of taxonomically diverse bacteria ${ }^{49-52}$. These essential oils were also chosen due to being found in several edible herbs ${ }^{53-54}$. Halogenated phenols were chosen because of their extensive evaluation and high activity 40,55 . Select alkylphenols were chosen for their antimicrobial and antifouling activity ${ }^{56-57}$. Several alkoxyphenols were selected due a variety alkoxy phenols studied for antimicrobial activity ${ }^{58-59}$. Two non-phenolic compounds were also chosen for this study, menthol for its structural similarity to thymol and 5-fluoro-2-((trichloromethyl)thio)isoindoline-1,3-dione (21b) for its similarity to the fungicide Folpet.

The trichloromethylanesulfenimide group that has been employed here on select phenols is the active antimicrobial pharmacophore in the broad-spectrum commercial fungicides Captan and Folpet. Captan and Folpet are phthalimide derivatives and are commonly used for protection of fruit and vegetable crops. Their activity is attributed to their reactivity with thiols and are active against a wide range of fungal diseases ${ }^{60-61}$. Significantly, these compounds have been shown not to possess carcinogenic, mutagenic, or teratogenic threats to humans ${ }^{62}$. 
In this study, the trichloromethylsulfenate esters of a variety of phenolic compounds were synthesized and evaluated against both planktonic cells and biofilms. The bacteria chosen for evaluation were $P$. aeruginosa, a Gram-negative bacterium and $S$. epidermidis, a Gram-positive bacterium. These bacteria were also selected for their prevalence in hospitals ${ }^{63-65}$ as well as their propensity to form biofilms ${ }^{66-68}$. Although the concept of biofilms was presented as early as the 1960 's, the study of behavioural variations in biofilms such as, nutrient uptake, gene expression and increased tolerance did not arise until more recently ${ }^{69-72}$. Biofilm research is an emerging field which has been rapidly gaining interest in light of new technologies in 3D modelling, imaging, anti-biofilm strategies and analytical tools ${ }^{73-75}$ as well as recent research emphasizing clinical relevance ${ }^{70,76}$. These also sheds light in the need to for novel strategies for the treatment and eradication of biofilms including antibacterial small natural molecules, peptides, and lipids ${ }^{77-}$ 82 .

\section{Results and discussion}

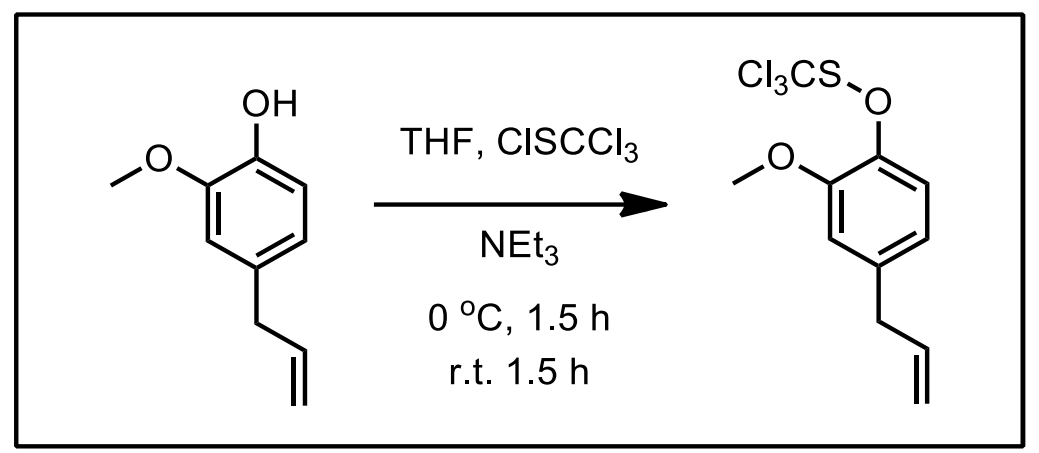

Scheme 1 Representative synthesis, using eugenol $(8 a)$.

In this study, 25 sulfenate esters of small phenols were synthesized. This synthesis was accomplished by treating each phenol with trichloromethyl hypochlorothioite in either THF or diethyl ether with triethylamine at $0{ }^{\circ} \mathrm{C}$ for $1.5 \mathrm{~h}$ and then allowing the reaction mixture to stir for $1.5 \mathrm{~h}$ at room temperature (Scheme 1$)$.

Sulfenate esters were more potent than their parent compounds 92 percent of the time. For example, on average, trichloromethylsulfenate esters were 9 times more potent than parent compounds against $S$. epidermidis and 17 times more potent towards $P$. aeruginosa in planktonic assays (Figure 1). Against biofilms, sulfenate esters were on average 4 times more potent towards $S$. epidermidis and 3.8 times more potent towards $P$. aeruginosa. It was also observed that towards biofilms, phenols and sulfenates were less potent compared to planktonic cells, a phenomenon that has widely been observed in previous studies ${ }^{3,68,71,83-85}$. The relative potencies of the precursor phenols and the corresponding sulfenate esters against both planktonic cells and biofilms will be discussed in turn.

\subsection{Disinfectant activities in the planktonic state}

\subsubsection{Parent phenols}


The most potent parent phenols against planktonic cells were 4-heptyloxyphenol (7a), 4-chloro-2methylphenol (16a), 3,4-dichlorophenol (14a), 2,4-dimethylphenol (3a), 6-(1-methylethyl)-3methylphenol (thymol) (1a), and 3-(1-methylethyl)-6-methylphenol (carvacrol) (4a) against both $S$. epidermidis and P. aeruginosa (Figure 1). Compounds 16a and 14a both possess at least one chlorine group on the aromatic ring, and although $p$-fluorophenol (15a) also possesses a halogen on the aromatic ring, it was significantly less potent against both $S$. epidermidis and $P$. aeruginosa (Figure 1). This is congruous with previous studies demonstrating that chlorine, which is more electron withdrawing than fluorine, increases the potency of the parent phenols to a greater extent $^{40}$. Compounds 1a, 3a and 4a all have either isopropyl or methyl groups in both the ortho and para positions while 7a has a para heptyloxy group (Figure 1). In contrast to 1a, 3a and 4a, compound 5a (2,6-diisopropylphenol) has two isopropyl groups in the ortho positions and possesses significantly lower potency. This is likely due to the higher degree of steric hindrance around the phenolic hydroxyl. 


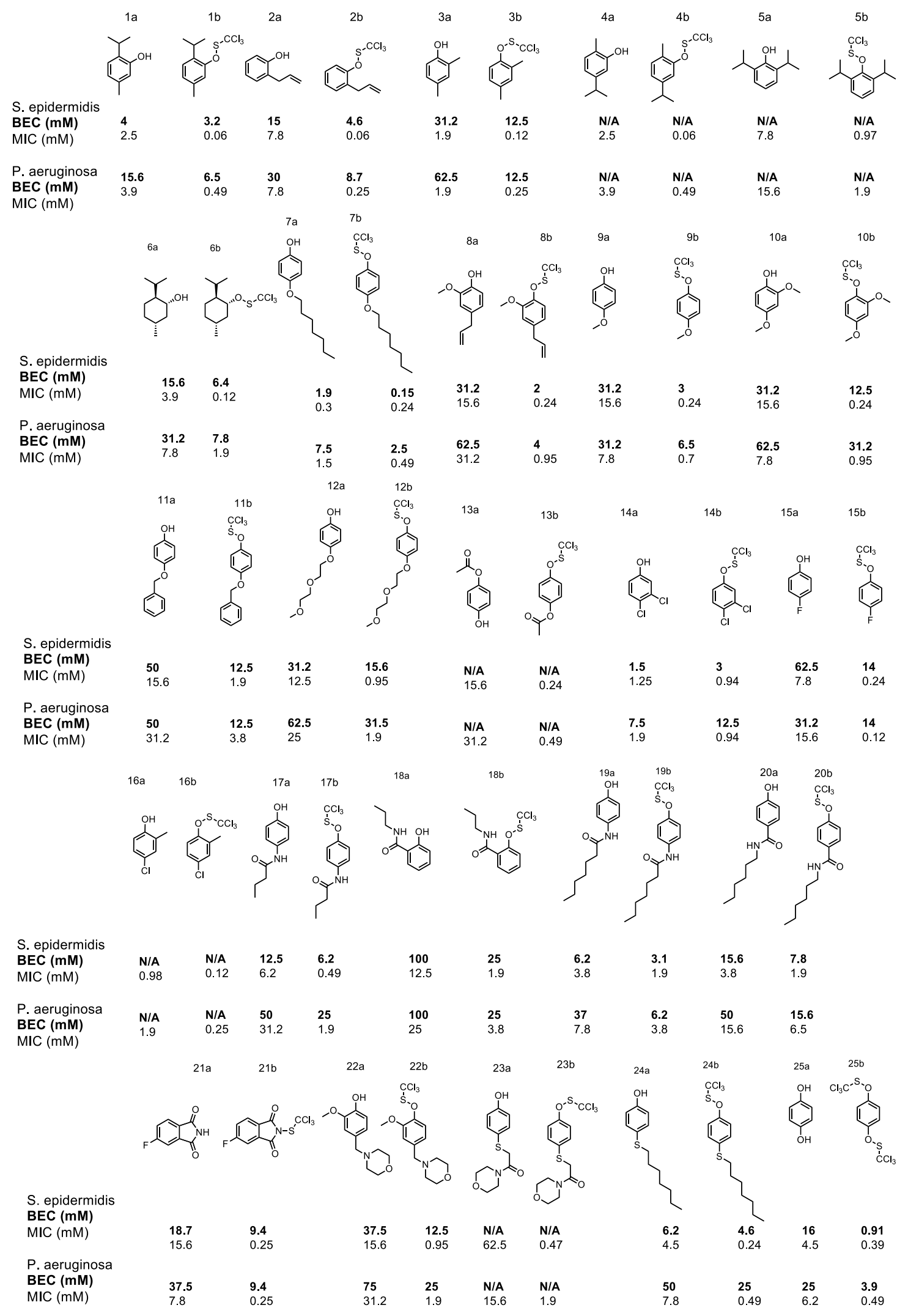

Figure 1 Parent phenols and corresponding sulfenate esters and their MICs and BECs 
Compound 7a had the lowest MIC towards both bacteria, making it of particular interest since it is considerably more active than the corresponding 4-methoxy and 2,4-dimethoxy derivatives, 9a and 10a (Table 1), which is less lipophilic. In light of this observation, two additional compounds in this series were synthesized and examined to evaluate the influence of lipophilicity on activity; these being 4-(benzyloxy)phenol (11a) and 4-(2-(2-methoxyethoxy)ethoxy)phenol (12a). Compound 12a was chosen for its near identical side chain length, when compare to 7a, and the increase hydrophilicity imparted by the oxygens within the side chain. Significantly, both of these structural alterations led to a marked decrease in activity compared to 7a (Table 1). In addition, 24a which differs from 7a solely by possessing a sulfur in place of oxygen, was evaluated and was found to be less potent than $7 \mathbf{a}$ against both bacteria.

Table 1 MICs of phenols $7 a, 9 a, 10 a, 11 a, 12 a$ and $24 a$.

\begin{tabular}{ccc}
\hline \multicolumn{3}{c}{ Minimum Inhibitory Concentrations $(\mathrm{mM})$} \\
\hline Compounds & S. epidermidis & P. aeruginosa \\
\hline $\mathbf{7 a}$ & 0.3 & 1.5 \\
$\mathbf{9 a}$ & 15.6 & 7.8 \\
$\mathbf{1 0 a}$ & 15.6 & 7.8 \\
$\mathbf{1 1 a}$ & 15.6 & 31.2 \\
$\mathbf{1 2 a}$ & 12.5 & 25 \\
$\mathbf{2 4 a}$ & 4.5 & 7.8 \\
\hline
\end{tabular}

Based on these results, a second SAR study was conducted with compounds 17a, 19a and 20a, which all possess an amide chain in either the para position (Table 2). Compounds 17a and 19a were chosen to compare amide chain length, as 17a has a 4-butanamide group while 19a has a 4heptanamide group, which is predicted to increase lipophilicity. Compound 20a was chosen for the comparison of nitrogen placement in the amide side chain, vis a vis "amide inversion". Accordingly, compound 19a ( $\mathrm{N}$-(4-hydroxyphenyl) heptanamide) has the amide nitrogen on the aromatic ring, while 20a (N-hexyl-4-hydroxybenzamide) has the carbonyl of the amide group attached to the aromatic ring. This structural alteration was performed to access effects of electron donating and electron withdrawing amide groups of the same length. An additional compound, 18a, was also evaluated for similar reasons to compare to 17a, although here the butanamide group was placed in the 2- position.

Table 2 MICs of phenols 17a, 18a, 19a, 20a.

\begin{tabular}{ccc}
\hline \multicolumn{2}{c}{ Minimum Inhibitory Concentrations $(\mathrm{mM})$} \\
\hline Compounds & S. epidermidis & P. aeruginosa \\
\hline $\mathbf{1 7 a}$ & 6.2 & 31.2 \\
$\mathbf{1 8 a}$ & 12.5 & 25 \\
$\mathbf{1 9 a}$ & 3.8 & 7.8 \\
$\mathbf{2 0 a}$ & 3.8 & 15.6 \\
\hline
\end{tabular}


Phenol 19a was the most potent compound in this series overall, although 20a shared the same potency against $S$. epidermidis (Table 2). It was observed that, 19a was more potent than 17a towards both bacteria, continuing the trend seen earlier that longer alkyl chain length does increase potency towards planktonic cells. Between 17a and 18a, 17a was the more potent isomer against $S$. epidermidis but not against $P$. aeruginosa. This evaluation also suggests that the length of the alkyl chain has a greater affect than nitrogen placement with respect to the aromatic ring.

(-)-Menthol (6a) was selected due to its structural similarities to thymol (1a), and since it is nonphenolic. Menthol, like thymol, has been studied for its antimicrobial activity ${ }^{86-87}$. It should be noted that 6a was far less active than 1a toward both bacterial strains used in this study.

\subsubsection{Trichloromethylsulfenate esters}

It was observed that, in general, more potent parent phenols produced more potent sulfenate esters, although this trend could not reliably be used to predict activity in all cases. The most potent sulfenates against $S$. epidermidis were, in descending order, $\mathbf{1 b}, \mathbf{2 b}, \mathbf{4 b}, \mathbf{3 b}$ and $\mathbf{1 6 b}$. For $P$. aeruginosa the most potent sulfenates were $\mathbf{1 5 b}, \mathbf{2 b}, \mathbf{3 b}$ followed by $\mathbf{1 6} \mathbf{b}$. As seen with the parent phenols, the sulfenate esters $\mathbf{3 b}$, and $\mathbf{1 6} \mathbf{b}$ are among the most potent disinfecting agents towards planktonic cells of both bacteria (Figure ). Likewise, 1a, 3a and 4a were also among the most potent towards planktonic S. epidermidis. In contrast, sulfenates $\mathbf{2 b}$ and $\mathbf{1 5 b}$ showed significant potency when their parent phenols did not. Conversely, phenols 7a and 14a showed exceptional potency towards both bacteria while the corresponding sulfenates $\mathbf{7 b}$ and $\mathbf{1 4 b}$ did not share this characteristic (Figure ).

In consonance with the prior SAR study, the series of sulfenate esters $7 \mathbf{b}, \mathbf{9 b}, \mathbf{1 0 b}, \mathbf{1 1 b}, \mathbf{1 2 b}$ and 24b showed a similar trend to the corresponding phenols towards planktonic cells. Derivatives $\mathbf{7 b}$, $\mathbf{9 b}, \mathbf{1 0 b}$ and $\mathbf{2 4 b}$ shared the highest potency towards $S$. epidermidis while $\mathbf{7 b}$ and $\mathbf{2 4 b}$ were the most potent towards $P$. aeruginosa in this series (Error! Reference source not found.). Sulfenate 11b was least potent towards both bacteria, as was seen with phenols. It was interesting to note that, in contrast to sulfenates, the 4-alkoxyphenol 7a was significantly more potent than its 4(thioalkyl) counterpart, 24a (Table 1).

Table 3 MICs of sulfenates $7 b, 9 b, 10 b, 11 b, 12 b, 24 b$.

\begin{tabular}{ccc}
\hline \multicolumn{3}{c}{ Minimum Inhibitory Concentrations (mM) } \\
\hline Compounds & S. epidermidis & P. aeruginosa \\
\hline 7b & 0.24 & 0.49 \\
9b & 0.24 & 0.7 \\
$\mathbf{1 0 b}$ & 0.24 & 0.95 \\
$\mathbf{1 1 b}$ & 1.9 & 3.8 \\
$\mathbf{1 2 b}$ & 0.95 & 1.9 \\
$\mathbf{2 4 b}$ & 0.24 & 0.49 \\
\hline
\end{tabular}

In the SAR study involving amides, a trend consistent with parent compounds was not observed. Compound 17b was the most potent sulfenate towards both bacteria, whereas the most potent parents were 19a and 20a against $S$. epidermidis and 19a towards $P$. aeruginosa (Table 4). 
Similarly, 20b was the least potent sulfenate in the amide series, while the least potent parent was 18a towards $S$. epidermidis and 17a towards $P$. aeruginosa. This further demonstrates that trends in parent compounds can not necessarily be used to predict trends in their corresponding sulfenate ester derivatives.

Table 3 MICs of sulfenates $17 b, 18 b, 19 b, 20 b$.

\begin{tabular}{ccc}
\hline \multicolumn{3}{c}{ Minimum Inhibitory Concentrations (mM) } \\
\hline Compounds & S. epidermidis & P. aeruginosa \\
\hline 17b & 0.49 & 1.9 \\
$\mathbf{1 8 b}$ & 1.9 & 3.8 \\
$\mathbf{1 9 b}$ & 1.9 & 3.8 \\
$\mathbf{2 0 b}$ & 1.9 & 6.5 \\
\hline
\end{tabular}

Compounds $\mathbf{6 b}$ and $\mathbf{2 1 b}$ were evaluated separately against planktonic cells. Compound $\mathbf{6 b}$ was among the six most potent sulfenates against $S$. epidermidis, sharing an MIC with $\mathbf{3 b}$ and $\mathbf{1 6 b}$ (Figure ). Compound 21b was in the five most potent compounds towards $P$. aeruginosa, sharing an MIC with $\mathbf{2 b}, \mathbf{3 b}$ and $\mathbf{1 6 b}$.

MICs of sulfenate esters were, in general, statistically significantly lower than the MIC of the parent phenols. A two-tailed t test was performed on four select phenol/sulfenate ester pairs; $\mathbf{3 a} / \mathbf{b}$, $\mathbf{1 0 a} / \mathbf{b}, \mathbf{1 3 a} / \mathbf{b}$ and $\mathbf{1 6} \mathbf{a} / \mathbf{b}$. Compounds $10 \mathbf{a} / \mathbf{b}$ and $\mathbf{1 3 a} / \mathbf{b}$ were chosen due to the large discrepancy in potency observed between the parent phenol and the sulfenate. Compounds $\mathbf{3 a} / \mathbf{b}$ and $\mathbf{1 6} \mathbf{a} / \mathbf{b}$ were chosen because the potency between parent phenols and sulfenate esters was the least dramatic of the 25 compound pairs evaluated. The $p$-value of $\mathbf{2 a / b}$ against $S$. epidermidis was calculated to be 0.043 and against $P$. aeruginosa 0.0028 . The $p$-value of $\mathbf{1 0 a} / \mathbf{b}$ against $S$. epidermidis is 0.039 and against $P$. aeruginosa is 0.031 . The $p$-value of $\mathbf{1 3 a} / \mathbf{b}$ against $S$. epidermidis is 0.0039 and against $P$. aeruginosa was calculated to be $2.8 \times 10^{-5}$. The $p$-values for $\mathbf{1 6 a} / \mathbf{b}$ were 0.00051 and 0.0028 against $S$. epidermidis and $P$. aeruginosa respectively.

\subsection{Disinfectant activity against biofilms:}

For comparison, the anti-parasitic drug nitazoxanide and the antibiotics metronidazole and tobramycin were evaluated for activity towards $S$. epidermidis and $P$. aeruginosa biofilms. Nitazoxanide is an antidiarrheal commonly used to treat strains of Cryptosporidium, Blastocystis and Giardia and is believed to interfere with pyruvate:ferredoxin oxidoreductase (PFOR) enzymedependent electron transfer reaction ${ }^{88-90}$. Nitazoxanide has also been shown to inhibit biofilm formation in S. epidermidis ${ }^{91}$ and Enteroaggregative Escherichia coli ${ }^{92}$ as well as decrease the viability of Clostridioides difficile biofilms ${ }^{93}$. Although, the efficacy of the drug to eradicate biofilms has yet to be evaluated, as it is here. The BEC of nitazoxanide was found to be $50 \mathrm{mM}$ towards $S$. epidermidis and $3.12 \mathrm{mM}$ towards $P$. aeruginosa.

Metronidazole is a nitroimidazole used to treat a variety of bacterial and parasitic infections and is most commonly used to treat infections related to inflammatory disorders of the gastrointestinal tract. Metronidazole is often used to treat Gram-negative, Gram-positive and Gram-variable anaerobic bacteria, as well as protozoans such as Giardia lamblia ${ }^{94}$. It has been shown to exhibit lower activity towards biofilms such as that of Helicobacter pylori ${ }^{95}$ and Clostridium difficile ${ }^{96-}$ 
${ }^{97}$ although has also been evaluated in tandem with several other antibiotics, resulting in improved activity against Enterococcus faecalis and Candida albicans biofilms ${ }^{98}$. Against S. epidermidis the BEC of metronidazole was 6.25 and against $P$. aeruginosa was $50 \mathrm{mM}$.

Tobramycin is an antibiotic that inhibits protein synthesis, used to treat Gram-negative bacteria. Tobramycin is commonly used to treat bacterial pneumonia, bacterial eye infections and has been extensively studied against biofilms ${ }^{99-100}$. A study by Høiby et. al. showed that the inhibitory properties towards $P$. aeruginosa biofilms were lower than that towards planktonic cells, concluding that biofilms are tolerant to the clinically recommended dose of the antibiotic ${ }^{101}$. SansSerramitjana et. al. evaluated the antimicrobial activity of nanoencapsulated tobramycin; finding that nanoencapsulation did improve the ability of tobramycin to eradicate $P$. aeruginosa biofilms and in this suggesting the strategy of lipid carries to deliver the drug, overcoming drug resistance to tobramycin ${ }^{102}$. Tobramycin was in part chosen due the known antimicrobial resistance of $P$. aeruginosa, making it a valuable comparison to this series of novel antimicrobials ${ }^{103-105 .}$ Tobramycin was found to have a BEC of $18 \mathrm{mM}$ towards $S$. epidermidis and $0.6 \mathrm{mM}$ and $P$. aeruginosa.

\subsubsection{Parent phenols}

Based on the observations from planktonic cell assays, eighteen parent phenols and the corresponding sulfenate esters, were chosen for evaluation against biofilms. Compounds 1a, 3a, 7a, and 14a were chosen for their high potency towards planktonic cells (Figure ). Compounds 2a, 8a, 15a, 10a, 17a and 22a were selected due to the large increase in potency between the moderately active parent phenols and corresponding sulfenate esters (Figure ). Compounds 7a, 9a, 10a, 11a, 12a, 24a, 17a, 18a, 19a and 20a were selected for the purpose of continuing the two SAR studies conducted with planktonic cells. Compound 25a was chosen since the corresponding sulfenate ester possess two trichloromethylsulfenate ester groups. Additionally, the non-phenolic compounds 6a and 21a were chosen, 6a as an aliphatic alcohol bearing structural similarity to 1a and 21a for its similarity to the imide corresponding to the commercial fungicide Folpet. Neither compound showed significant activity towards either bacterium.

As a continuation of the previous SAR study involving phenols 7a, 9a, 10a, 11a, 12a and 24a against planktonic cells, this series was subsequently evaluated against biofilms (Table 5). In accordance with planktonic trends, 7a was the most potent phenol in this series towards both bacteria

Table 5 BECs of phenols 7a, 9a, 10a, 11a, 12a and 24a.

\begin{tabular}{ccc}
\hline \multicolumn{3}{c}{ Biofilm Eradication Concentration $(\mathrm{mM})$} \\
\hline Compounds & S. epidermidis & P. aeruginosa \\
\hline 7a & 1.9 & 7.5 \\
9a & 31.2 & 31.2 \\
$\mathbf{1 0 a}$ & 31.2 & 62.5 \\
$\mathbf{1 1 a}$ & 50 & 50 \\
$\mathbf{1 2 a}$ & 31.2 & 62.5 \\
$\mathbf{2 4 a}$ & 6.2 & 50 \\
\hline
\end{tabular}


In the SAR study involving amides, 19a was the most potent phenol towards both bacteria. In contrast, 18a was the least potent compound towards both bacteria, whereas in planktonic assays 17a was least potent towards $P$. aeruginosa. In both SAR studies, the more potent phenols against planktonic cells did in general have lower BECs as well, though the trend in potency was not always predictable for all compounds (Table 6).

Table 4 BECs of phenols $17 a, 18 a, 19 a$ and $20 a$.

\begin{tabular}{ccc}
\hline \multicolumn{3}{c}{ Biofilm Eradication Concentration $(\mathrm{mM})$} \\
\hline Compounds & S. epidermidis & P. aeruginosa \\
\hline 17a & 12.5 & 50 \\
18a & 100 & 100 \\
19a & 6.2 & 37 \\
20a & 15.6 & 50 \\
\hline
\end{tabular}

Among the additional compounds selected for biofilm evaluations, the majority were alkyl phenols, along with two halophenols and hydroquinone (Table 7). The most potent phenols towards $S$. epidermidis biofilms were, in descending order, 14a, 7a, 1a, 19a and 24a. Against $P$. aeruginosa, the most potent phenols were 14a, 7a, 1a, 25a, and 2a; whereas here, 14a and 7a shared the same BEC. Out of these seven compounds, only three (1a, 7a and 14a) were among the active most against planktonic cells. These results further reveal that activity towards planktonic cells cannot be reliably used to predict potency towards biofilms.

Table 7 BECs for allyl-and halo-phenols as well as hydroquinone

\begin{tabular}{ccc}
\hline \multicolumn{3}{c}{ Biofilm Eradication Concentration $(\mathrm{mM})$} \\
\hline Compounds & S. epidermidis & P. aeruginosa \\
\hline 1a & 4 & 15.6 \\
$\mathbf{2 a}$ & 15 & 30 \\
$\mathbf{3 a}$ & 31.2 & 62.5 \\
$\mathbf{8 a}$ & 31.2 & 62.5 \\
$\mathbf{1 4 a}$ & 1.5 & 7.5 \\
$\mathbf{1 5 a}$ & 62.5 & 31.2 \\
$\mathbf{2 2 a}$ & 37.5 & 75 \\
$\mathbf{2 5 a}$ & 16 & 25 \\
\hline
\end{tabular}

\subsubsection{Sulfenate esters}

The most potent sulfenate esters towards $S$. epidermidis were $\mathbf{7 b}, \mathbf{2 5 b}, \mathbf{8 b}, \mathbf{9 b}$ and $\mathbf{1 4 b}$. For $P$. aeruginosa the most active sulfenates were $\mathbf{2 5 b}, \mathbf{8 b}, \mathbf{1 9 b}, \mathbf{9 b}$ and $\mathbf{1 b}$. Interestingly, out of these seven compounds, none were among the most potent towards planktonic cells, which was unexpected as it differs from the trend observed with parent phenols. However, there were similarities between most potent phenols and sulfenates towards biofilms. For example, the phenols corresponding to sulfenates $\mathbf{1 b}, \mathbf{7 b}, \mathbf{1 4 b}, \mathbf{1 9 b}$ and $\mathbf{2 5 b}$ were among the most potent parents. 
In consonance with the previous SAR study involving 4-alkoxyphenols, sulfonates $\mathbf{7 b}, \mathbf{9 b}, \mathbf{1 0 b}$, 11b, 12b and the 4-(heptylthio)phenyl sulfenate $\mathbf{2 4 b}$ were evaluated towards biofilms (Table 8). Sulfenate $\mathbf{7 b}$ was the most potent compound against biofilms in this series. Against planktonic cells however, $\mathbf{7 b}$ had the same MIC as $\mathbf{9 b}, \mathbf{1 0 b}$ and $\mathbf{2 4 b}$ against $S$. epidermidis and $\mathbf{2 4 b}$ against $P$. aeruginosa (Error! Reference source not found. 3). This observation supports the finding that long, saturated alkoxy chains generally increase potency more so than a diethylene glycol derived chain or a benzyl group. It is also noteworthy that the replacement of the oxygen by sulfur (e.g. 7b $\rightarrow \mathbf{2 4 b}$ ) results in a substantial decrease in activity.

Table 8 BECs for sulfenates $7 b, 9 b, 10 b, 11 b, 12 b$ and $24 b$.

\begin{tabular}{ccc}
\hline \multicolumn{3}{c}{ Biofilm Eradication Concentration (mM) } \\
\hline Compounds & S. epidermidis & P. aeruginosa \\
\hline 7b & 0.15 & 2.5 \\
9b & 3 & 6.5 \\
$\mathbf{1 0 b}$ & 12.5 & 31.2 \\
$\mathbf{1 1 b}$ & 12.5 & 12.5 \\
$\mathbf{1 2 b}$ & 15.8 & 31.2 \\
$\mathbf{2 4 b}$ & 4.6 & 25 \\
\hline
\end{tabular}

The SAR study involving amides showed that $\mathbf{1 9 b}$ was the most potent derivative towards both bacteria, which is not congruent with what was observed with planktonic cells, where $\mathbf{1 7 b}$ was the most active (Table 9). Compound $\mathbf{1 8 b}$ was the least potent sulfenate in this series against biofilms while 20b was least potent towards planktonic cells.

Table 9 BEC for sulfenates $17 b, 18 b, 19 b$ and $20 b$.

\begin{tabular}{ccc}
\hline \multicolumn{3}{c}{ Biofilm Eradication Concentration $(\mathrm{mM})$} \\
\hline Compounds & S. epidermidis & P. aeruginosa \\
\hline 17b & 6.2 & 25 \\
18b & 25 & 25 \\
19b & 3.1 & 6.2 \\
20b & 7.8 & 15.6 \\
\hline
\end{tabular}

Sulfenates selected for biofilm evaluations which were not part of the two preceding SAR studies, are assembled in table 10. Among these, monosulfenates $\mathbf{8 b}$ and $\mathbf{1 b}$ were the most active towards both strains of bacteria. It is not surprising that that bis(sulfenate) $\mathbf{2 5} \mathbf{b}$ showed excellent activity towards biofilms as well. Sulfenate $\mathbf{2 2 b}$, which contains a basic morpholine group, exhibited low potency in against both bacterial strains. In this case, it had been hoped that the presence of a basic amine might increase permeability by way of protonation, resulting in enhanced solubility. Nonphenolic sulfenates $\mathbf{6 b}$ and $\mathbf{2 1 b}$ were also evaluated towards biofilms (Figure 1). Neither compound showed significant activity, with $\mathbf{6 b}$ showing only half the potency of $\mathbf{1 b}$ towards $S$. epidermidis. 
Table 5 BECs for allyl-and halo-sulfenates as well as the bis(sulfenate) $25 b$.

\begin{tabular}{ccc}
\hline \multicolumn{3}{c}{ Biofilm eradication concentration $(\mathrm{Mm})$} \\
\hline Compounds & S. epidermidis & P. aeruginosa \\
\hline $\mathbf{1 b}$ & 3.2 & 6.5 \\
$\mathbf{2 b}$ & 4.6 & 8.7 \\
$\mathbf{3 b}$ & 12.5 & 12.5 \\
$\mathbf{8 b}$ & 2 & 4 \\
$\mathbf{1 4 b}$ & 3 & 12.5 \\
$\mathbf{1 5 b}$ & 14 & 14 \\
$\mathbf{2 2 b}$ & 12.5 & 25 \\
$\mathbf{2 5 b}$ & 0.91 & 3.9 \\
\hline
\end{tabular}

\subsection{Comparison of phenols and sulfenates}

Among parents and sulfenates chosen for the alkoxy and alkylthio side chains SAR study, (7a/b, $9 \mathbf{a} / \mathbf{b}, 10 \mathbf{a} / \mathbf{b} 11 \mathbf{a} / \mathbf{b}, \mathbf{1 2 a} / \mathbf{b}$ and $\mathbf{2 4 b}$ ) it was shown that the more potent phenols did typically produce more potent sulfenate esters when evaluated against biofilms. The exception to this being 12a which has a lower BEC than 11a, while 11b has a lower BEC than 12b against $S$. epidermidis biofilms. It is therefore evident that $\mathbf{7 a} / \mathbf{b}$ were the most potent compounds in this series overall. In the amide SAR study, between $17 \mathbf{a} / \mathbf{b}$ and $19 \mathbf{a} / \mathbf{b}$, it was observed that $19 \mathbf{a} / \mathbf{b}$ was typically more potent than $17 \mathbf{a} / \mathbf{b}$ with the exception of $19 \mathrm{~b}$ being less potent towards planktonic $P$. aeruginosa. This relationship demonstrates that increasing alkyl chain length, as with $\mathbf{7 a} / \mathbf{b}$, will in general increase potency of phenols and sulfenates. Between the isomers $19 \mathbf{a} / \mathbf{b}$ and $20 \mathbf{a} / \mathbf{b}, 19 \mathbf{a} / \mathbf{b}$ were generally the more potent isomers in both planktonic and biofilm assays, although possessing the same MICs towards S. epidermidis.

Overall, a correlation between increased potency towards planktonic cells leading to increased potency in biofilms was observed through evaluation of phenols and corresponding sulfenate esters, with the exception of $\mathbf{1 4 a} / \mathbf{b}$ and $\mathbf{7 a} / \mathbf{b}$ against $P$. aeruginosa biofilms (Figure ). This type of relationship has been previously described by others as well ${ }^{106}$, although, it has also been observed that activity towards planktonic cells cannot reliably be used to predict that same compounds potency against biofilms. This has been demonstrated most recently by Walsh et. al. (2019) ${ }^{107}$ and is further supported here by the foregoing results.

The BECs of sulfenate esters when compared to their corresponding parent phenols were generally statistically significantly lower. A two-tailed $t$ test was performed on four select phenol/sulfenate ester pairs; $8 \mathbf{a} / \mathbf{b}, 9 \mathbf{9} / \mathbf{b}, \mathbf{1 2 a} / \mathbf{b}$ and $\mathbf{1 7 a} / \mathbf{b}$. Compounds $8 \mathbf{a} / \mathbf{b}$ and $9 \mathbf{a} / \mathbf{b}$ were chosen due to the large discrepancy in potency observed between the parent phenol and the sulfenate. Compounds $12 \mathbf{a} / \mathbf{b}$ and 17a/b were chosen because the potency between parent phenols and sulfenate esters was the least dramatic of the 25 compound pairs evaluated. The $p$-value of $\mathbf{8 a} / \mathbf{b}$ against $S$. epidermidis was calculated to be 0.00012 and against $P$. aeruginosa 0.044 . The $p$-value of $\mathbf{9 a / b}$ against $S$. epidermidis is 0.044 and against $P$. aeruginosa is 0.0091 . The $p$-value of $\mathbf{1 2 a} / \mathbf{b}$ against $S$. epidermidis is 0.0038 and against $P$. aeruginosa was calculated to be 0.019 . The $p$-value for $\mathbf{1 7 a} \mathbf{a} / \mathbf{b}$ was 0.019 against both $S$. epidermidis and $P$. aeruginosa. 


\subsection{Comparison of sulfenates and known antibacterial compounds}

The sulfenate esters which showed the highest potency towards biofilms were $\mathbf{7 b}$ towards $S$. epidermidis, with a BEC of $0.15 \mathrm{mM}$ (Table 8), and $\mathbf{2 5 b}$ towards $P$. aeruginosa with, a BEC of $3.9 \mathrm{mM}$ (Table 10). Among the commercially available antimicrobials evaluated here, metronidazole exhibited the highest potency towards $S$. epidermidis biofilms with a BEC of 6.25 $\mathrm{mM}$ and tobramycin towards $P$. aeruginosa with a BEC of $0.6 \mathrm{mM}$. Against $S$. epidermidis, nine of 19 sulfenate esters had a lower BEC than metronidazole, 18 out of 19 had a lower BEC than tobramycin and all 19 had a lower BEC than nitazoxanide. Against $P$. aeruginosa, tobramycin and nitazoxanide had a lower BEC than all sulfenate esters, although all 19 sulfenate esters had a lower BEC than metronidazole.

Since Staphylococci and Pseudomonas are both facultative anaerobes and metronidazole is most affective towards anaerobic bacteria, it was predicted that the majority of sulfenate esters would more potent towards both bacteria. Tobramycin is typically used to treat Gram-negative infections, and as shown here was significantly more potent towards $P$. aeruginosa than sulfenate esters. Nitazoxanide is used to treat both Gram-positive and negative bacteria, although is more often used to treat anaerobes. Sulfenate esters were statistically more potent towards $S$. epidermidis than $P$. aeruginosa, so it is no surprise that the majority of sulfenates showed greater potency towards $S$. epidermidis but not towards $P$. aeruginosa when compared to known antimicrobials.

\subsection{Analysis of sulfenate degradation}

Sulfenate esters are expected to hydrolyze to the parent phenols in aqueous solutions via cleavage of the S-O bond. In a study to determine the hydrolytic stability of sulfenates, the decomposition of (4-fluorophenoxy)trichloromethylsulfane (15b) in water was monitored via $\mathrm{F}^{19}$ NMR (Figure 2). In this study, the gradual appearance of 4 -fluorophenol (15a) $\left({ }^{19} \mathrm{~F}\right.$ NMR $\left.\delta:-125.1 \pm 0.1\right)$ was clearly revealed.

(1)




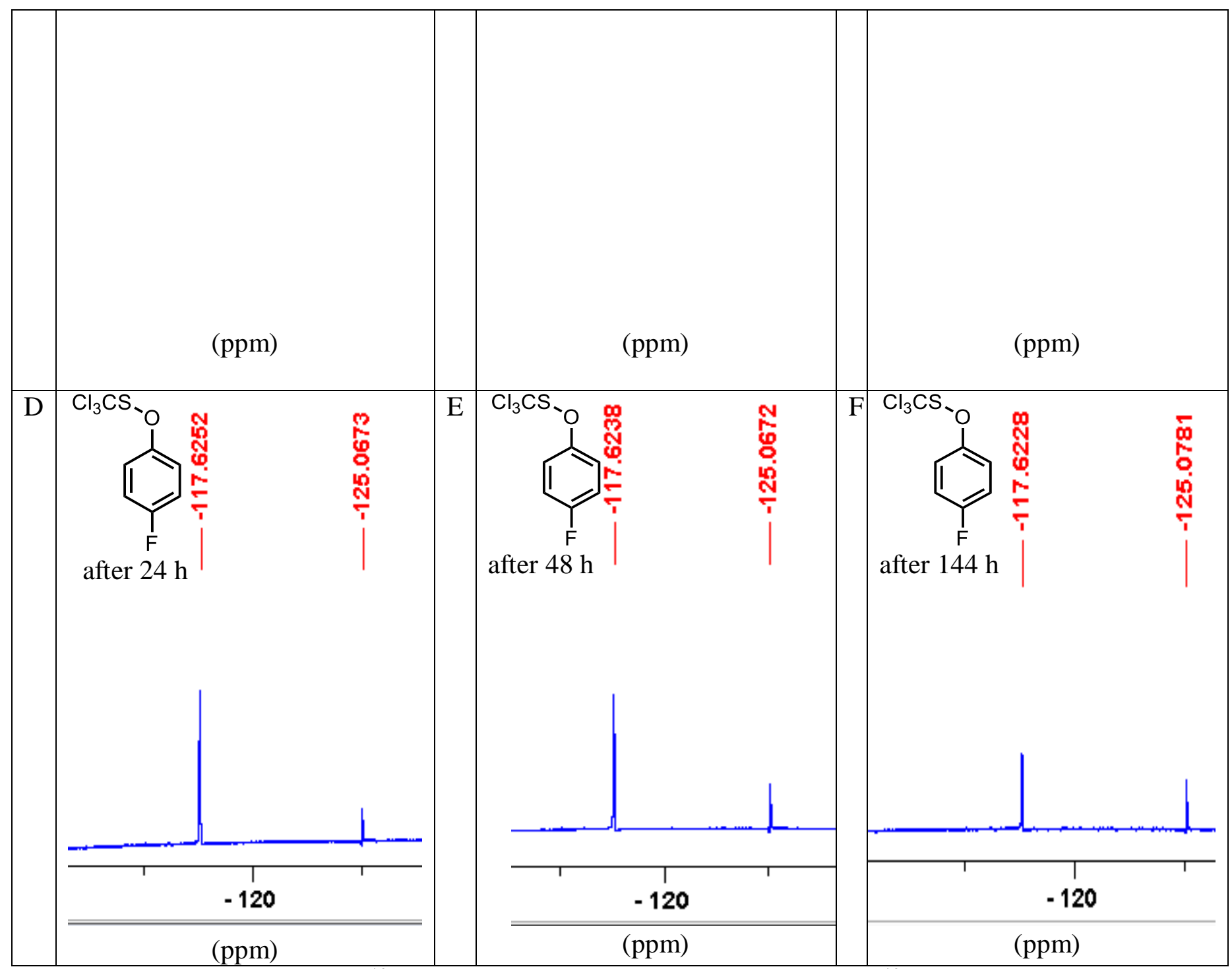

Figure 2. (A) $\mathrm{F}^{19} \mathrm{NMR}$ of $p$-fluorophenol (15a) in $\mathrm{D}_{2} \mathrm{O}$; (B) $\mathrm{F}^{19}$ NMR of (4fluorophenoxy)(trichloromethyl)sulfane (15b) in $\mathrm{D}_{2} \mathrm{O}$ at $0 \mathrm{~h} ;(\mathrm{C}) \mathrm{F}^{19} \mathrm{NMR}$ of (4fluorophenoxy)(trichloromethyl)sulfane in $\mathrm{D}_{2} \mathrm{O}$ after $12 \mathrm{~h}$; (D) $\mathrm{F}^{19}$ NMR of (4fluorophenoxy)(trichloromethyl)sulfane in $\mathrm{D}_{2} \mathrm{O}$ after $24 \mathrm{~h}$; (E) $\mathrm{F}^{19} \mathrm{NMR}$ of (4fluorophenoxy)(trichloromethyl)sulfane in $\mathrm{D}_{2} \mathrm{O}$ after $48 \mathrm{~h}$; (F) $\mathrm{F}^{19} \mathrm{NMR}$ of (4fluorophenoxy)(trichloromethyl)sulfane in $\mathrm{D}_{2} \mathrm{O}$ after $144 \mathrm{~h}$.

After $12 \mathrm{~h}(\mathbf{C})$, there were no signs of decomposition of the sulfenate (15b). However, after $24 \mathrm{~h}$ (D), the sulfenate ester (15b) had begun to hydrolyze to the parent phenol. A continuation of this decomposition was observed (E and $\mathbf{F}$ ), and after $144 \mathrm{~h}$, the sulfenate ester approached a 1:1 ratio with the corresponding phenol $(\mathbf{F})$. This shows that while sulfenate esters do hydrolyze in the presence of water, they are stable for up to $12 \mathrm{~h}$. This is crucial since the biological assays employed here require a $12 \mathrm{~h}$ exposure time for each phenol and sulfenate ester derivative in planktonic and biofilm assays. Accordingly, sulfenates should be robust for the entirety of exposure time. 


\section{Conclusion}

This study has shown that sulfenate esters generally exhibit a significant increase in potency toward planktonic cells and biofilms of S. epidermidis and P. aeruginosa when compared to their phenolic counterparts. For example, it was found that on average sulfenates were 9 times more potent than the parent phenols against $S$. epidermidis and 17 times more potent towards $P$. aeruginosa in planktonic assays. Against biofilms, sulfenates were 4 times more potent towards both $S$. epidermidis and $P$. aeruginosa. The findings presented here also reveal that the most potent compounds towards planktonic cells are not always the most potent towards biofilms. Likewise, the most potent parent phenols do not consistently produce the most potent sulfenate esters. SAR studies have shown that placement, configuration, and alkyl chain length of functional groups does affect potency of the parent phenols as well as the derivatized sulfenates. An additional study, the monitored hydrolysis of $\mathbf{1 5 b}$ by ${ }^{19} \mathrm{~F} \mathrm{NMR}$, has shown that the stability of a representative sulfenate ester in aqueous solution is approximately $24 \mathrm{~h}$. Further experimentation to determine clinical significance could be conducted with biofilms eradications measurements being determined with biofilms grown on different surfaces, such as metal and plastic, to mimic those found in clinical settings.

\section{Materials and Methods}

\subsection{Synthetic reagents and bacteria}

All organic reagents for chemical synthesis were purchased from commercial sources and used as received without further purification. P. aeruginosa (PA01) and S. epidermidis (35984) were obtained from American Type Culture Collection (ATCC). All bacteria were sub-cultured onto tryptic soy agar (TSA) plates and incubated at $37{ }^{\circ} \mathrm{C}$ for $24 \mathrm{~h}$. Single colonies were transferred from the plates and inoculated into $25 \mathrm{~mL}$ tryptic soy broth (TSB) in Erlenmeyer flasks. Cultures were incubated $37{ }^{\circ} \mathrm{C}$ for $24 \mathrm{~h}$ and $10 \mu \mathrm{L}$ of culture was transferred into $25 \mathrm{~mL}$ of TSB. The absorbance was read at $600 \mathrm{~nm}\left(\mathrm{OD}_{600}\right)$ using a spectrophotometer, adjusted to an $\mathrm{OD}$ of 0.05 and standardized to $10^{6}-10^{7} \mathrm{CFU} / \mathrm{mL}$.

\subsection{Synthesis}

Preparation of (2,4-dimethylphenoxy)trichloromethyl sulfane (3b). A $25 \mathrm{~mL}$ round-bottomed flask equipped with a magnetic stirring bar was charged with 2,4-dimethylphenol $(610 \mathrm{mg}, 5$ mmol, 1 equiv) and anhydrous diethyl ether $(10 \mathrm{~mL})$. The mixture was cooled to $0{ }^{\circ} \mathrm{C}$ and anhydrous triethylamine $(0.77 \mathrm{~mL}, 5.5 \mathrm{mmol}, 1.1$ equiv) was added. To the stirred mixture was added trichloromethyl hypochlorothioite $(0.57 \mathrm{~mL}, 5.25 \mathrm{mmol}, 1.05$ equiv) dropwise. The reactant mixture was stirred at $0{ }^{\circ} \mathrm{C}$ for $1.5 \mathrm{~h}$ and allowed to warm to room temperature and stirred for an additional $12 \mathrm{~h}$. To the resulting mixture was added pentane $(5 \mathrm{~mL})$ which was then filtered through celite and washed with $t$-butyl methyl ether $(3 \times 5 \mathrm{~mL})$. The solvents were evaporated in vacuo to provide the title compound $1.03 \mathrm{~g} \mathrm{(76 \% )}$ as a yellow oil. ${ }^{\mathbf{1}} \mathbf{H} \mathbf{~ N M R}(300 \mathrm{MHz}, \mathrm{CDCl} 3)$ : $\delta 7.23(\mathrm{dd}, J=843,2.62 \mathrm{~Hz}, 1 \mathrm{H}), 7.00(\mathrm{dd}, J=2.62,0.45 \mathrm{~Hz}, 1 \mathrm{H}), 6.98(\mathrm{dd}, J=8.43,0.45 \mathrm{~Hz}$, $1 \mathrm{H}), 2.39$ (s, 3H), $2.31(\mathrm{~s}, 3 \mathrm{H}) . \mathbf{C}^{13} \mathbf{N M R}(500 \mathrm{MHz}, \mathrm{CDCl} 3): \delta 16.16(\mathrm{CH} 3), 20.55(\mathrm{CH} 3), 116.19$ (C), $121.49(\mathrm{CH}), 130(\mathrm{C}), 132.02(\mathrm{C}), 133.81(\mathrm{CH}), 136.73(\mathrm{CH}), 156.05(\mathrm{C}) . \mathrm{H}^{1}$ and $\mathrm{C}^{13} \mathrm{NMR}$ was used to confirm the purity of all sulfenate esters and can be found in the Supplementary Material.

\subsection{Efficacy of phenols and derivatives on inhibiting planktonic cells}


Minimum inhibitory concentrations (MICs) of all compounds evaluated here were determined using a 96-well plate assay previously described by Xie ${ }^{36}$. 96-wellplates were inoculated with bacterial culture, prepared as stated in section 2.1, followed by exposure to the phenol or sulfenate. Plates were incubated at $37{ }^{\circ} \mathrm{C}$ for $12 \mathrm{~h}$. A plate reader was used to analyze bacterial inhibition. Samples were diluted in dimethyl sulfoxide (DMSO) and DMSO controls were conducted as the negative control. Experiments were done in biological triplicate with technical duplicates. Tests for statistical significance were calculated with a two-tailed t-test assuming unequal variances. All compounds were readily soluble in DMSO and no solvent carriers were used in this procedure.

\subsection{Efficacy of phenols and derivatives on biofilms}

In methods similar to those published by Walsh. et. al. ${ }^{107}$, both strains were cultured as described above and biofilms were grown in Costar polystyrene 96-well plates at $37{ }^{\circ} \mathrm{C}$. After $24 \mathrm{~h}$ of incubation, the planktonic-phase cells were gently removed, and the wells were washed three times with PBS. Wells were filled with $150 \mu \mathrm{L}$ dilutions of the compound being evaluated. The 96-well plates were incubated for an additional $12 \mathrm{~h}$ at $37{ }^{\circ} \mathrm{C}$. The media was gently removed and each well filled with $150 \mu \mathrm{L}$ PBS and the biofilm broken up through stirring with sterile, wooden rods. Three tenfold dilutions of each sample were drop plated on TSA plates and incubated for $24 \mathrm{~h}$. The biofilm eradication concentration (BEC) was determined to be the lowest concentration at which no bacterial growth occurred. This procedure was modelled on previously reported procedures according to Pitts ${ }^{108}$. Two negative controls were conducted with $150 \mu \mathrm{L}$ PBS and with $150 \mu \mathrm{L}$ DMSO in the absence of disinfecting agents. Positive disinfectant controls were conducted using nitazoxanide, metronidazole and tobramycin. Experiments were done in biological triplicate with technical duplicates. All compounds were readily soluble, and no solvent carriers were used in this procedure.

\subsection{Measuring rate of hydrolysis of sulfenate derivatives}

(4-fluorophenoxy)trichloromethylsulfane (15b) (13 $\mathrm{mg}, 0.05 \mathrm{mmol})$ was dissolved in water (1 $\mathrm{mL}$ ). An aliquot was taken every $12 \mathrm{~h}$ and dissolved in $\mathrm{D}_{2} \mathrm{O}$ in an NMR tube. $\mathrm{F}^{19}$ NMR was performed to measure the appearance of the parent compound, $p$-fluorophenol (15a) in the sample. A $0 \mathrm{~h} \mathrm{~F}^{19} \mathrm{NMR}$ of the sulfane derivative (15b) was taken, as was of the pure parent compound (15a) for reference (Figure 2). Technical triplicates were done.

\section{Conflicts of Interest}

The authors declare that there is no conflict of interest regarding the publication of this paper.

\section{Acknowledgements}

Generous funding for this research was provided by the National Institute for General Medical Science. GM 116949 


\section{Supplementary Material}

A general procedure for and the characterization of all compounds can be found in the supplementary materials by clicking the link.

\section{References}

1. Floyd, K. A.; Eberly, A. R.; Hadjifrangiskou, M., 3 - Adhesion of bacteria to surfaces and biofilm formation on medical devices. In Biofilms and Implantable Medical Devices, Deng, Y.; Lv, W., Eds. Woodhead Publishing: 2017; pp 47-95.

2. Garrett, T. R.; Bhakoo, M.; Zhang, Z., Bacterial adhesion and biofilms on surfaces. Progress in Natural Science 2008, 18 (9), 1049-1056.

3. Donlan, R. M., Biofilms: microbial life on surfaces. Emerging infectious diseases 2002, 8 (9), 88190.

4. Gilbert, P.; Das, J.; Foley, I., Biofilm Susceptibility to Antimicrobials. Advances in Dental Research 1997, $11(1), 160-167$.

5. Singh, S.; Singh, S. K.; Chowdhury, I.; Singh, R., Understanding the Mechanism of Bacterial Biofilms Resistance to Antimicrobial Agents. Open Microbiol J 2017, 11, 53-62.

6. Domenech, M.; Ramos-Sevillano, E.; García, E.; Moscoso, M.; Yuste, J., Biofilm formation avoids complement immunity and phagocytosis of Streptococcus pneumoniae. Infect Immun 2013, 81 (7), 2606-2615.

7. Leid, J. G., Bacterial Biofilms Resist Key Host Defenses. Microbe 2009, 4, 66-70.

8. Conlon, B. P.; Rowe, S. E.; Lewis, K., Persister Cells in Biofilm Associated Infections. In Biofilmbased Healthcare-associated Infections: Volume II, Donelli, G., Ed. Springer International Publishing: Cham, 2015; pp 1-9.

9. Balaban, N. Q.; Merrin, J.; Chait, R.; Kowalik, L.; Leibler, S., Bacterial persistence as a phenotypic switch. Science 2004, 305 (5690), 1622-5.

10. Dorr, T.; Vulic, M.; Lewis, K., Ciprofloxacin causes persister formation by inducing the TisB toxin in Escherichia coli. PLoS biology 2010, 8 (2), e1000317.

11. Patel, R., Biofilms and antimicrobial resistance. Clinical orthopaedics and related research 2005, (437), 41-7.

12. Cerca, N.; Oliveira, R.; Azeredo, J., Susceptibility of Staphylococcus epidermidis planktonic cells and biofilms to the lytic action of staphylococcus bacteriophage K. Letters in applied microbiology 2007, 45 (3), 313-7.

13. Stewart, P. S., Antimicrobial Tolerance in Biofilms. Microbiol Spectr 2015, 3 (3), 10.1128/microbiolspec.MB-0010-2014.

14. Flemming, H. C.; Wingender, J.; Szewzyk, U.; Steinberg, P.; Rice, S. A.; Kjelleberg, S., Biofilms: an emergent form of bacterial life. Nature reviews. Microbiology 2016, 14 (9), 563-75.

15. Donlan, R. M.; Costerton, J. W., Biofilms: survival mechanisms of clinically relevant microorganisms. Clin Microbiol Rev 2002, 15 (2), 167-93.

16. Campanac, C.; Pineau, L.; Payard, A.; Baziard-Mouysset, G.; Roques, C., Interactions between biocide cationic agents and bacterial biofilms. Antimicrobial agents and chemotherapy 2002, 46 (5), 1469-74.

17. Davenport, E. K.; Call, D. R.; Beyenal, H., Differential protection from tobramycin by extracellular polymeric substances from Acinetobacter baumannii and Staphylococcus aureus biofilms. Antimicrobial agents and chemotherapy 2014, 58 (8), 4755-61. 
18. Mah, T.-F. C.; O'Toole, G. A., Mechanisms of biofilm resistance to antimicrobial agents. Trends in Microbiology 2001, 9 (1), 34-39.

19. Romling, U.; Balsalobre, C., Biofilm infections, their resilience to therapy and innovative treatment strategies. Journal of internal medicine 2012, 272 (6), 541-61.

20. Lewis, K., Riddle of Biofilm Resistance. Antimicrobial agents and chemotherapy 2001, 45 (4), 999-1007.

21. Hughes, G.; Webber, M. A., Novel approaches to the treatment of bacterial biofilm infections. $\mathrm{Br}$ J Pharmacol 2017, 174 (14), 2237-2246.

22. Stewart, P. S., Antimicrobial Tolerance in Biofilms. Microbiology spectrum 2015, 3 (3).

23. Yan, Z.; Huang, M.; Melander, C.; Kjellerup, B. V., Dispersal and Inhibition of Biofilms Associated with Infections. Journal of applied microbiology 2019.

24. Worthington, R. J.; Richards, J. J.; Melander, C., Small molecule control of bacterial biofilms.

Organic \& biomolecular chemistry 2012, 10 (37), 7457-74.

25. Stone, P. W., Economic burden of healthcare-associated infections: an American perspective. Expert review of pharmacoeconomics \& outcomes research 2009, 9 (5), 417-22.

26. Elkins, J. G.; Hassett, D. J.; Stewart, P. S.; Schweizer, H. P.; McDermott, T. R., Protective role of catalase in Pseudomonas aeruginosa biofilm resistance to hydrogen peroxide. Applied and environmental microbiology 1999, 65 (10), 4594-600.

27. Khakimova, M.; Ahlgren, H. G.; Harrison, J. J.; English, A. M.; Nguyen, D., The stringent response controls catalases in Pseudomonas aeruginosa and is required for hydrogen peroxide and antibiotic tolerance. Journal of bacteriology 2013, 195 (9), 2011-20.

28. Leung, C. Y.; Chan, Y. C.; Samaranayake, L. P.; Seneviratne, C. J., Biocide resistance of Candida and Escherichia coli biofilms is associated with higher antioxidative capacities. The Journal of hospital infection 2012, 81 (2), 79-86.

29. Guerin-Mechin, L.; Dubois-Brissonnet, F.; Heyd, B.; Leveau, J. Y., Specific variations of fatty acid composition of Pseudomonas aeruginosa ATCC 15442 induced by quaternary ammonium compounds and relation with resistance to bactericidal activity. Journal of applied microbiology 1999, 87 (5), 735-42. 30. Mechin, L.; Dubois-Brissonnet, F.; Heyd, B.; Leveau, J. Y., Adaptation of Pseudomonas aeruginosa ATCC 15442 to didecyldimethylammonium bromide induces changes in membrane fatty acid composition and in resistance of cells. Journal of applied microbiology 1999, 86 (5), 859-66.

31. Bjorland, J.; Sunde, M.; Waage, S., Plasmid-borne smr gene causes resistance to quaternary ammonium compounds in bovine Staphylococcus aureus. J Clin Microbiol 2001, 39 (11), 3999-4004.

32. De Beer, D.; Srinivasan, R.; Stewart, P. S., Direct measurement of chlorine penetration into biofilms during disinfection. Applied and environmental microbiology 1994, 60 (12), 4339-44.

33. Jang, A.; Szabo, J.; Hosni, A. A.; Coughlin, M.; Bishop, P. L., Measurement of chlorine dioxide penetration in dairy process pipe biofilms during disinfection. Applied microbiology and biotechnology 2006, 72 (2), 368-76.

34. Vazquez-Sanchez, D.; Galvao, J. A.; Mazine, M. R.; Gloria, E. M.; Oetterer, M., Control of Staphylococcus aureus biofilms by the application of single and combined treatments based in plant essential oils. Int J Food Microbiol 2018, 286, 128-138.

35. Ziebuhr, W.; Hennig, S.; Eckart, M.; Kranzler, H.; Batzilla, C.; Kozitskaya, S., Nosocomial infections by Staphylococcus epidermidis: how a commensal bacterium turns into a pathogen. International journal of antimicrobial agents 2006, 28 Suppl 1, S14-20.

36. Xie, J. L.; Singh-Babak, S. D.; Cowen, L. E., Minimum Inhibitory Concentration (MIC) Assay for Antifungal Drugs. Bio-protocol 2012, 2 (20), e252.

37. Campos, F. M.; Couto, J. A.; Figueiredo, A. R.; Tóth, I. V.; Rangel, A. O. S. S.; Hogg, T. A., Cell membrane damage induced by phenolic acids on wine lactic acid bacteria. International Journal of Food Microbiology 2009, 135 (2), 144-151. 
38. Pinheiro, P. F.; Menini, L. A. P.; Bernardes, P. C.; Saraiva, S. H.; Carneiro, J. W. M.; Costa, A. V.; Arruda, T. R.; Lage, M. R.; Goncalves, P. M.; Bernardes, C. O.; Alvarenga, E. S.; Menini, L., Semisynthetic Phenol Derivatives Obtained from Natural Phenols: Antimicrobial Activity and Molecular Properties. J Agric Food Chem 2018, 66 (1), 323-330.

39. Alves, M. J.; Ferreira, I. C.; Froufe, H. J.; Abreu, R. M.; Martins, A.; Pintado, M., Antimicrobial activity of phenolic compounds identified in wild mushrooms, SAR analysis and docking studies. Journal of applied microbiology 2013, 115 (2), 346-57.

40. Suter, C. M., Relationships between the Structure and the Bactericidal Properties of Phenols. Chemical Reviews 1941, 28 (2), 269-299.

41. Knobloch, K.; Pauli, A.; Iberl, B.; Weigand, H.; Weis, N., Antibacterial and Antifungal Properties of Essential Oil Components. Journal of Essential Oil Research 1989, 1 (3), 119-128.

42. Das, S.; Singh, V. K.; Dwivedy, A. K.; Chaudhari, A. K.; Upadhyay, N.; Singh, A.; Deepika; Dubey, N. K., Antimicrobial activity, antiaflatoxigenic potential and in situ efficacy of novel formulation comprising of Apium graveolens essential oil and its major component. Pesticide Biochemistry and Physiology 2019, 160, 102-111.

43. Ultee, A.; Bennik, M. H. J.; Moezelaar, R., The phenolic hydroxyl group of carvacrol is essential for action against the food-borne pathogen Bacillus cereus. Applied and environmental microbiology 2002, 68 (4), 1561-1568.

44. Tepe, B.; Daferera, D.; Sokmen, A.; Sokmen, M.; Polissiou, M., Antimicrobial and antioxidant activities of the essential oil and various extracts of Salvia tomentosa Miller (Lamiaceae). Food chemistry 2005, 90 (3), 333-340.

45. Nazzaro, F.; Fratianni, F.; De Martino, L.; Coppola, R.; De Feo, V., Effect of essential oils on pathogenic bacteria. Pharmaceuticals (Basel, Switzerland) 2013, 6 (12), 1451-1474.

46. Maris, P., Modes of action of disinfectants. Revue scientifique et technique (International Office of Epizootics) 1995, 14 (1), 47-55.

47. Lucchini, J. J.; Corre, J.; Cremieux, A., Antibacterial activity of phenolic compounds and aromatic alcohols. Research in Microbiology 1990, 141 (4), 499-510.

48. Lambert, R. J. W.; Skandamis, P. N.; Coote, P. J.; Nychas, G.-J. E., A study of the minimum inhibitory concentration and mode of action of oregano essential oil, thymol and carvacrol. Journal of applied microbiology 2001, 91 (3), 453-462.

49. Prieto, M. C.; Lapaz, M. I.; Lucini, E. I.; Pianzzola, M. J.; Grosso, N. R.; Asensio, C. M., Thyme and Suico essential oils: promising natural tools for Potato Common Scab Control. Plant biology (Stuttgart, Germany) 2019.

50. Pinheiro, P. F.; Menini, L. A. P.; Bernardes, P. C.; Saraiva, S. H.; Carneiro, J. W. M.; Costa, A. V.; Arruda, T. R.; Lage, M. R.; Gonçalves, P. M.; Bernardes, C. d. O.; Alvarenga, E. S.; Menini, L., Semisynthetic Phenol Derivatives Obtained from Natural Phenols: Antimicrobial Activity and Molecular Properties. Journal of Agricultural and Food Chemistry 2018, 66 (1), 323-330.

51. Ali, S. M.; Khan, A. A.; Ahmed, I.; Musaddiq, M.; Ahmed, K. S.; Polasa, H.; Rao, L. V.; Habibullah, C. M.; Sechi, L. A.; Ahmed, N., Antimicrobial activities of Eugenol and Cinnamaldehyde against the human gastric pathogen Helicobacter pylori. Annals of clinical microbiology and antimicrobials 2005, 4, 20.

52. Marino, M.; Bersani, C.; Comi, G., Impedance measurements to study the antimicrobial activity of essential oils from Lamiaceae and Compositae. Int J Food Microbiol 2001, 67 (3), 187-95.

53. Chaieb, K.; Hajlaoui, H.; Zmantar, T.; Kahla-Nakbi, A. B.; Rouabhia, M.; Mahdouani, K.; Bakhrouf, A., The chemical composition and biological activity of clove essential oil, Eugenia caryophyllata (Syzigium aromaticum L. Myrtaceae): a short review. Phytotherapy research : PTR 2007, 21 (6), 501-6. 
54. Kumari, P.; Mishra, R.; Arora, N.; Chatrath, A.; Gangwar, R.; Roy, P.; Prasad, R., Antifungal and Anti-Biofilm Activity of Essential Oil Active Components against Cryptococcus neoformans and Cryptococcus laurentii. Frontiers in microbiology 2017, 8, 2161.

55. Cronin, M. T. D.; Schultz, T. W., Structure-toxicity relationships for phenols to Tetrahymena pyriformis. Chemosphere 1996, 32 (8), 1453-1468.

56. Etoh, H.; Ban, N.; Fujiyoshi, J.; Murayama, N.; Sugiyama, K.; Watanabe, N.; Sakata, K.; Ina, K.; Miyoshi, H.; Iwamura, H., Quantitative Analysis of the Antimicrobial Activity and Membraneperturbation Potency of Antifouling Para-substituted Alkylphenols. Bioscience, Biotechnology, and Biochemistry 1994, 58 (3), 467-469.

57. Denyer, S. P.; Hugo, W. B.; Witham, R. F., THE ANTIBACTERIAL ACTION OF A SERIES OF 4-NALKYLPHENOLS. Journal of Pharmacy and Pharmacology 1980, 32 (S1), 27P-27P.

58. Harper, D., Coburn, R., Georgiades, C., Huntley, M. and Soshinsky, A. Non-halogenated naphthol compounds, antimicrobial compositions containing the same, and methods of using the same. European Patent 1409443A2, November 29, 2001.

59. Anand, S.; Deighton, M.; Livanos, G.; Morrison, P. D.; Pang, E. C. K.; Mantri, N., Antimicrobial Activity of Agastache Honey and Characterization of Its Bioactive Compounds in Comparison With Important Commercial Honeys. Front Microbiol 2019, 10 (263).

60. Bernard, B. K.; Gordon, E. B., An Evaluation of the Common Mechanism Approach to the Food Quality Protection Act: Captan and Four Related Fungicides, a Practical Example. International Journal of Toxicology 2000, 19 (1), 43-61.

61. Franz Müller, P. A., Paul Margot, Fungicides, Agricultural, 2. Individual Fungicides. In Ullmann's Encyclopedia of Industrial Chemistry, 2011.

62. Gupta, P. K., Chapter 24 - Herbicides and fungicides. In Biomarkers in Toxicology, Gupta, R. C., Ed. Academic Press: Boston, 2014; pp 409-431.

63. Akbari, F.; Kjellerup, B. V., Elimination of Bloodstream Infections Associated with Candida albicans Biofilm in Intravascular Catheters. Pathogens 2015, 4 (3), 457-69.

64. von Eiff, C.; Heilmann, C.; Herrmann, M.; Peters, G., Basic aspects of the pathogenesis of staphylococcal polymer-associated infections. Infection 1999, 27 (1), S7-S10.

65. Ziebuhr, W.; Hennig, S.; Eckart, M.; Kränzler, H.; Batzilla, C.; Kozitskaya, S., Nosocomial infections by Staphylococcus epidermidis: how a commensal bacterium turns into a pathogen. International journal of antimicrobial agents 2006, 28, 14-20.

66. Sakimura, T.; Kajiyama, S.; Adachi, S.; Chiba, K.; Yonekura, A.; Tomita, M.; Koseki, H.; Miyamoto, T.; Tsurumoto, T.; Osaki, M., Biofilm-Forming Staphylococcus epidermidis Expressing Vancomycin Resistance Early after Adhesion to a Metal Surface. BioMed Research International 2015, 2015, 8.

67. Büttner, H.; Mack, D.; Rohde, H., Structural basis of Staphylococcus epidermidis biofilm formation: mechanisms and molecular interactions. Front Cell Infect Microbiol 2015, 5, 14-14.

68. Götz, F., Staphylococcus and biofilms. Mol Microbiol 2002, 43 (6), 1367-1378.

69. Donlan, R. M.; Costerton, J. W., Biofilms: survival mechanisms of clinically relevant microorganisms. Clin Microbiol Rev 2002, 15 (2), 167-193.

70. Jefferson, K. K., What drives bacteria to produce a biofilm? FEMS microbiology letters 2004, 236 (2), 163-73.

71. Stewart, P. S., Mechanisms of antibiotic resistance in bacterial biofilms. International journal of medical microbiology : IJMM 2002, 292 (2), 107-13.

72. Stewart, P. S.; William Costerton, J., Antibiotic resistance of bacteria in biofilms. The Lancet 2001, 358 (9276), 135-138.

73. Franklin, M. J.; Chang, C.; Akiyama, T.; Bothner, B., New Technologies for Studying Biofilms. Microbiology spectrum 2015, 3 (4), 10.1128/microbiolspec.MB-0016-2014. 
74. Benjamin, A. D.; Abbasi, R.; Owens, M.; Olsen, R. J.; Walsh, D. J.; LeFevre, T. B.; Wilking, J. N., Light-based 3D printing of hydrogels with high-resolution channels. Biomedical Physics \& Engineering Express 2019, 5 (2), 025035.

75. Blackledge, M. S.; Worthington, R. J.; Melander, C., Biologically inspired strategies for combating bacterial biofilms. Current Opinion in Pharmacology 2013, 13 (5), 699-706.

76. Donlan, R. M., Biofilm Formation: A Clinically Relevant Microbiological Process. Clinical Infectious Diseases 2001, 33 (8), 1387-1392.

77. van Tilburg Bernardes, E.; Lewenza, S.; Reckseidler-Zenteno, S., Current Research Approaches to Target Biofilm Infections. Postdoc journal : a journal of postdoctoral research and postdoctoral affairs 2015, 3 (6), 36-49.

78. Garrison, A. T.; Huigens lii, R. W., Eradicating Bacterial Biofilms with Natural Products and Their Inspired Analogues that Operate Through Unique Mechanisms. Curr Top Med Chem 2016.

79. Dostert, M.; Belanger, C. R.; Hancock, R. E. W., Design and Assessment of Anti-Biofilm Peptides: Steps Toward Clinical Application. J Innate Immun 2019, 11 (3), 193-204.

80. de la Fuente-Nunez, C.; Reffuveille, F.; Haney, E. F.; Straus, S. K.; Hancock, R. E., Broad-spectrum anti-biofilm peptide that targets a cellular stress response. PLoS Pathog 2014, 10 (5), e1004152.

81. Brown, K. L.; Hancock, R. E., Cationic host defense (antimicrobial) peptides. Curr Opin Immunol 2006, 18 (1), 24-30.

82. Desbois, A. P.; Smith, V. J., Antibacterial free fatty acids: activities, mechanisms of action and biotechnological potential. Appl Microbiol Biotechnol 2010, 85 (6), 1629-42.

83. Bridier, A.; Briandet, R.; Thomas, V.; Dubois-Brissonnet, F., Resistance of bacterial biofilms to disinfectants: a review. Biofouling 2011, 27 (9), 1017-1032.

84. Hall, C. W.; Mah, T.-F., Molecular mechanisms of biofilm-based antibiotic resistance and tolerance in pathogenic bacteria. FEMS Microbiology Reviews 2017, 41 (3), 276-301.

85. Stewart, P. S.; Franklin, M. J., Physiological heterogeneity in biofilms. Nature Reviews Microbiology 2008, 6 (3), 199-210.

86. Singh, R.; Shushni, M. A. M.; Belkheir, A., Antibacterial and antioxidant activities of Mentha piperita L. Arabian Journal of Chemistry 2015, 8 (3), 322-328.

87. Trombetta, D.; Castelli, F.; Sarpietro, M. G.; Venuti, V.; Cristani, M.; Daniele, C.; Saija, A.; Mazzanti, G.; Bisignano, G., Mechanisms of antibacterial action of three monoterpenes. Antimicrobial agents and chemotherapy 2005, 49 (6), 2474-2478.

88. Somvanshi, V. S.; Ellis, B. L.; Hu, Y.; Aroian, R. V., Nitazoxanide: nematicidal mode of action and drug combination studies. Mol Biochem Parasitol 2014, 193 (1), 1-8.

89. Leung, A. K. C.; Leung, A. A. M.; Wong, A. H. C.; Sergi, C. M.; Kam, J. K. M., Giardiasis: An Overview. Recent Pat Inflamm Allergy Drug Discov 2019, 13 (2), 134-143.

90. Lee, S.; Harwood, M.; Girouard, D.; Meyers, M. J.; Campbell, M. A.; Beamer, G.; Tzipori, S., The therapeutic efficacy of azithromycin and nitazoxanide in the acute pig model of Cryptosporidium hominis. PLoS One 2017, 12 (10), e0185906.

91. Tchouaffi-Nana, F.; Ballard, T. E.; Cary, C. H.; Macdonald, T. L.; Sifri, C. D.; Hoffman, P. S., Nitazoxanide inhibits biofilm formation by Staphylococcus epidermidis by blocking accumulation on surfaces. Antimicrobial agents and chemotherapy 2010, 54 (7), 2767-74.

92. Shamir, E. R.; Warthan, M.; Brown, S. P.; Nataro, J. P.; Guerrant, R. L.; Hoffman, P. S., Nitazoxanide inhibits biofilm production and hemagglutination by enteroaggregative Escherichia coli strains by blocking assembly of AafA fimbriae. Antimicrobial agents and chemotherapy 2010, 54 (4), 1526-33.

93. Mathur, H.; Rea, M. C.; Cotter, P. D.; Hill, C.; Ross, R. P., The efficacy of thuricin CD, tigecycline, vancomycin, teicoplanin, rifampicin and nitazoxanide, independently and in paired combinations against Clostridium difficile biofilms and planktonic cells. Gut Pathog 2016, 8, 20-20. 
94. Freeman, C. D.; Klutman, N. E.; Lamp, K. C., Metronidazole. A therapeutic review and update. Drugs 1997, 54 (5), 679-708.

95. Yonezawa, H.; Osaki, T.; Hojo, F.; Kamiya, S., Effect of Helicobacter pylori biofilm formation on susceptibility to amoxicillin, metronidazole and clarithromycin. Microbial pathogenesis 2019, 132, 100 108.

96. Vuotto, C.; Moura, I.; Barbanti, F.; Donelli, G.; Spigaglia, P., Subinhibitory concentrations of metronidazole increase biofilm formation in Clostridium difficile strains. Pathogens and Disease 2015, 74 (2).

97. Vuotto, C.; Moura, I.; Barbanti, F.; Donelli, G.; Spigaglia, P., Subinhibitory concentrations of metronidazole increase biofilm formation in Clostridium difficile strains. Pathog Dis 2016, 74 (2).

98. Zancan, R. F.; Calefi, P. H. S.; Borges, M. M. B.; Lopes, M. R. M.; de Andrade, F. B.; Vivan, R. R.; Duarte, M. A. H., Antimicrobial activity of intracanal medications against both Enterococcus faecalis and Candida albicans biofilm. Microscopy Research and Technique 2019, 82 (5), 494-500.

99. Bothra, M.; Lodha, R.; Kabra, S. K., Tobramycin for the treatment of bacterial pneumonia in children. Expert Opin Pharmacother 2012, 13 (4), 565-71.

100. Wilhelmus, K. R.; Gilbert, M. L.; Osato, M. S., Tobramycin in ophthalmology. Surv Ophthalmol 1987, 32 (2), 111-22.

101. Høiby, N.; Henneberg, K.-Å.; Wang, H.; Stavnsbjerg, C.; Bjarnsholt, T.; Ciofu, O.; Johansen, U. R.; Sams, T., Formation of Pseudomonas aeruginosa inhibition zone during tobramycin disk diffusion is due to transition from planktonic to biofilm mode of growth. International journal of antimicrobial agents 2019, 53 (5), 564-573.

102. Sans-Serramitjana, E.; Jorba, M.; Fuste, E.; Pedraz, J. L.; Vinuesa, T.; Vinas, M., Free and Nanoencapsulated Tobramycin: Effects on Planktonic and Biofilm Forms of Pseudomonas.

Microorganisms 2017, 5 (3).

103. Nickel, J. C.; Ruseska, I.; Wright, J. B.; Costerton, J. W., Tobramycin resistance of Pseudomonas aeruginosa cells growing as a biofilm on urinary catheter material. Antimicrobial agents and chemotherapy 1985, 27 (4), 619.

104. Merlo, C. A.; Boyle, M. P.; Diener-West, M.; Marshall, B. C.; Goss, C. H.; Lechtzin, N., Incidence and Risk Factors for Multiple Antibiotic-Resistant Pseudomonas aeruginosa in Cystic Fibrosis. Chest 2007, 132 (2), 562-568.

105. Poole, K., Aminoglycoside Resistance in \&lt;em\&gt;Pseudomonas aeruginosa\&lt;/em\&gt. Antimicrobial agents and chemotherapy 2005, 49 (2), 479.

106. Gill, R. K.; Kumar, V.; Robijns, S. C. A.; Steenackers, H. P. L.; Van der Eycken, E. V.; Bariwal, J., Polysubstituted 2-aminoimidazoles as anti-biofilm and antiproliferative agents: Discovery of potent lead. European journal of medicinal chemistry 2017, 138, 152-169.

107. Walsh, D. J.; Livinghouse, T.; Goeres, D. M.; Mettler, M.; Stewart, P. S., Antimicrobial Activity of Naturally Occurring Phenols and Derivatives Against Biofilm and Planktonic Bacteria. Frontiers in Chemistry 2019, 7 (653).

108. Pitts, B.; Hamilton, M. A.; Zelver, N.; Stewart, P. S., A microtiter-plate screening method for biofilm disinfection and removal. Journal of microbiological methods 2003, 54 (2), 269-76. 


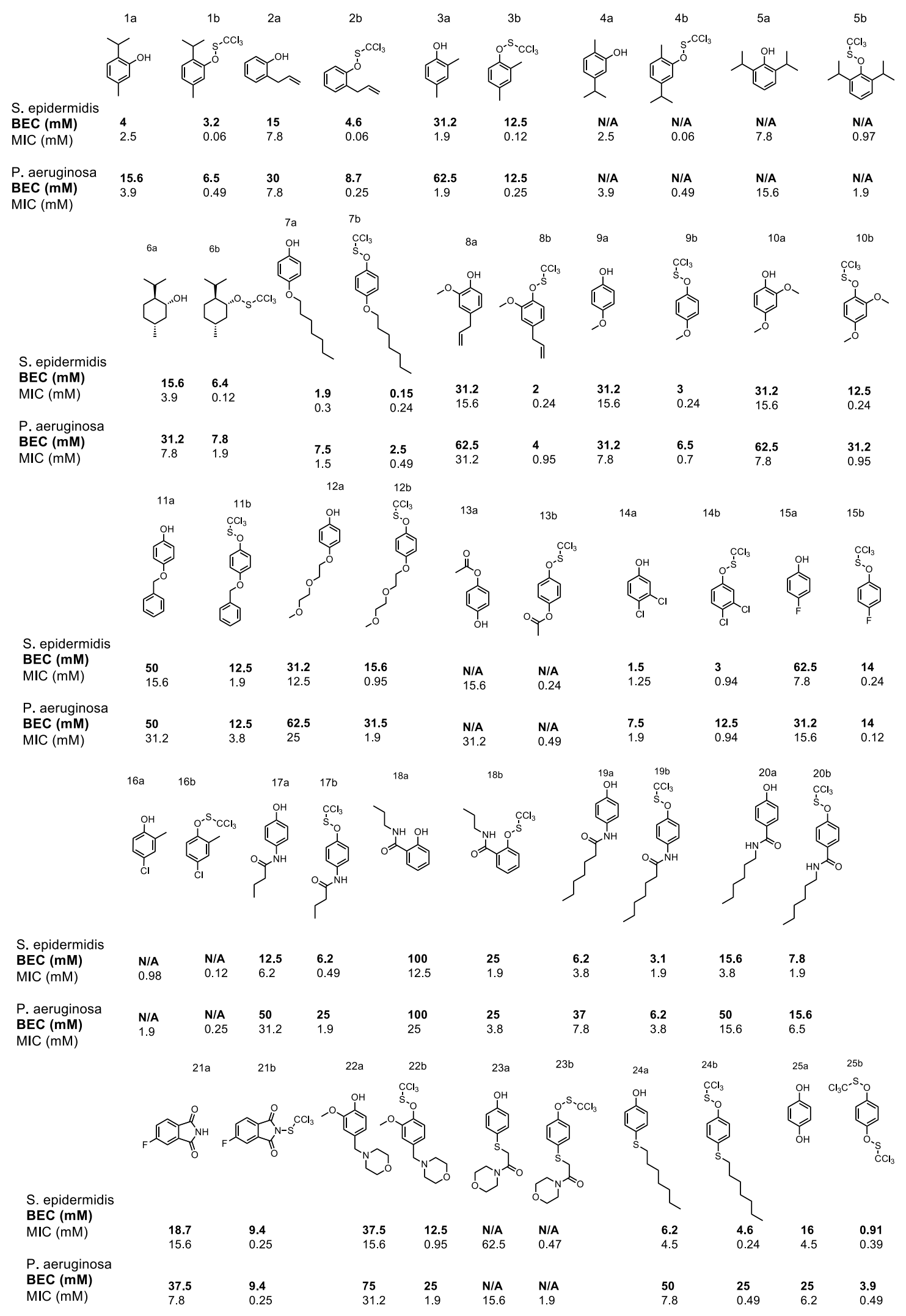

Figure 1 Parent phenols and corresponding sulfenate esters and their MICs and BECs 


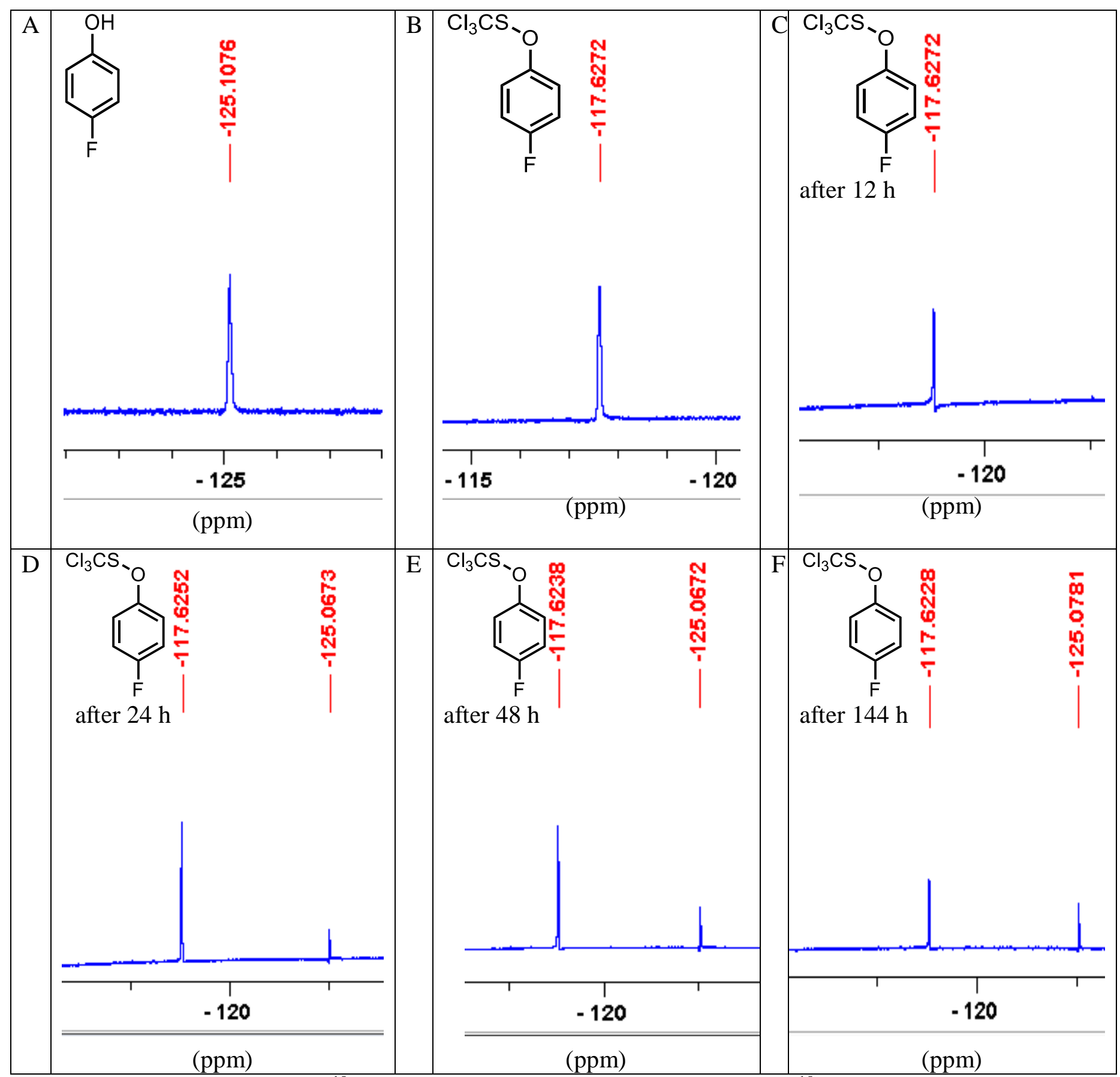

Figure 2 (A) $\mathrm{F}^{19}$ NMR of $p$-fluorophenol (15a) in $\mathrm{D}_{2} \mathrm{O}$; (B) $\mathrm{F}^{19}$ NMR of (4fluorophenoxy)(trichloromethyl)sulfane (15b) in $\mathrm{D}_{2} \mathrm{O}$ at $0 \mathrm{~h} ;(\mathrm{C}) \mathrm{F}^{19} \mathrm{NMR}$ of (4fluorophenoxy)(trichloromethyl)sulfane in $\mathrm{D}_{2} \mathrm{O}$ after $12 \mathrm{~h}$; (D) $\mathrm{F}^{19}$ NMR of (4fluorophenoxy)(trichloromethyl)sulfane in $\mathrm{D}_{2} \mathrm{O}$ after $24 \mathrm{~h}$; (E) $\mathrm{F}^{19} \mathrm{NMR}$ of (4fluorophenoxy)(trichloromethyl)sulfane in $\mathrm{D}_{2} \mathrm{O}$ after $48 \mathrm{~h}$; (F) $\mathrm{F}^{19} \mathrm{NMR}$ of (4fluorophenoxy)(trichloromethyl)sulfane in $\mathrm{D}_{2} \mathrm{O}$ after $144 \mathrm{~h}$. 


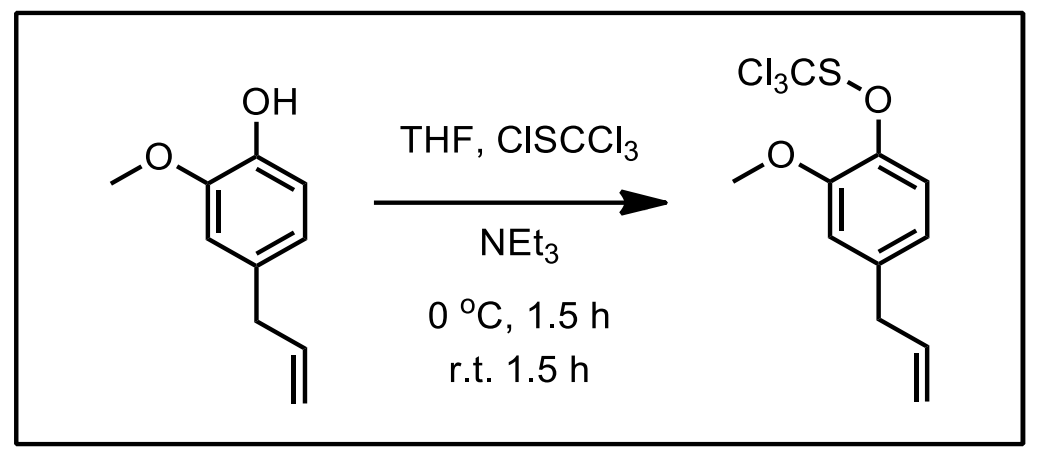

Scheme 1 Representative synthesis, using eugenol (8a). 
For Table of Contents Only

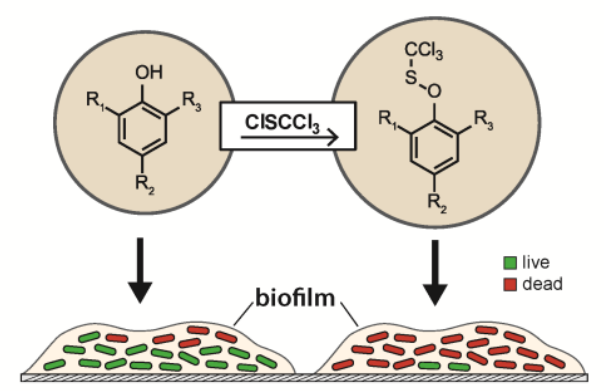

